\title{
Isolasi Dan Identifikasi Gelatin pada Sediaan Obat Tablet yang tidak Berbahan Aktif Protein
}

\author{
Dedy Suseno ${ }^{1)}$, Anna P Roswiem ${ }^{1)}$ \\ ${ }^{1)}$ Halal Research Center Universitas YARSI \\ Email : dedy.suseno@yarsi.ac.id
}

\begin{abstract}
Gelatin has many uses and not only on food products but also to the non food products like the raw material of the capsule, the raw material of cosmetic and medicine. In pharmaceutical industry, gelatin used in manufacture of soft and hard capsule and a binding material of tablet medicine. Gelatin is product hydrolysis of collagen and a point source of it from cow and pig bone and cow, pig and fish skin. On 2002, as many as $41 \%$ gelatin produced from the pig skin. This is a reflection of the number of gelatin from pig in the word market as well very large so it was worried that create insecurity for the community especially muslims to consume medicine who uses gelatin as a binding material of tablet medicine. The purpose of this research is for isolate gelatin in tablet medicine that the active ingredient not a protein make a ferris methode and indentify the gelatin use reagent biuret. From eleven sample was analyzed nine sample is contain gelatin and two sample isn't contain gelatin.
\end{abstract}

Key words : picric acid, gelatin, tablet medicine, ferris methode

\section{PENDAHULUAN}

Pengenalan gelatin kepada masyarakat saat ini merupakan hal yang penting karena gelatin banyak sekali kegunaannya dan bukan saja terbatas pada produk pangan tetapi juga pada produk non pangan seperti kapsul obat-obatan dalam cangkang kapsul, bahan kosmetika, dan bahan kedokteran gigi (dental material). Pada tahun 2002, produksi gelatin dunia mencapai 270 ribu ton kubik. Di antara produsen utama gelatin adalah negaranegara Eropa, Amerika Serikat, Amerika Selatan, serta negara-negara Asia seperti Indonesia, Thailand, Cina dan Jepang. Dari jumlah di atas, sebanyak $41 \%$ gelatin diproduksi dari kulit babi, $28.5 \%$ dari kulit sapi, dan $29.5 \%$ dari tulang sapi. Data ini menunjukkan bahwa gelatin yang diekstrak dari hewan babi masih mendominasi pasaran dunia (Jaswir 2007). Penggunaan gelatin babi yang cukup dominan dimungkinkan karena sifatnya yang lebih stabil dan biaya produksi yang lebih ekonomis, menghasilkan lebih sedikit limbah dan waktu pre-treatment yang lebih cepat dibandingkan dengan gelatin sapi (Hermanto 2015).
Gelatin merupakan senyawa polipeptida yang diperoleh dengan cara hidrolisis secara parsial dari kolagen yang diekstrak dari jaringan ikat dan tulang hewan (Zhang et al 2009). Gelatin merupakan campuran fraksi protein murni yang dihasilkan baik dengan hidrolisis parsial asam (gelatin tipe A) atau dengan hidrolisis parsial basa (gelatin tipe B) dari kolagen hewan yang diperoleh dari tulang sapi dan babi, serta kulit sapi, babi, dan ikan (Rowe et al 2009). Di bidang farmasi, gelatin kebanyakan digunakan dalm industri kapsul. Gelatin masih dianggap sebagai bahan terbaik untuk memproteksi obat-obatan dari udara, cahaya, uap air serta kontaminan mikroba (Sahilah et al 2012 dan Jaswir 2007). Selain itu, gelatin juga sering dijadikan sebagai bahan penstabil (stabilizer) dan bahan pengemulsi (emulsifier) terbaik untuk kebanyakan obatobatan sirup (Jaswir 2007).

Dalam industri farmasi, gelatin digunakan dalam pembuatan cangkang kapsul lunak dan keras, sebagai bahan pengikat tablet, sebagai bahan penstabil suplemen gizi, dan sebagai bahan pengemulsi obat-obatan yang berbentuk cairan dan pasta. Bahan tambahan dalam pembuatan tablet adalah semua bahan dalam 
tablet selain zat aktif (Voight 1994). Bahan tambahan tablet yang biasa digunakan yaitu bahan pengisi, bahan pengikat, bahan penghancur, dan bahan pelicin. Dari semua bahan itu, gelatin merupakan salah satu contoh bahan yang digunakan dalam bahan tambahan pembuatan tablet yaitu sebagai bahan pengikat (Banker dan Anderson 1994). Adanya laporan ditemukannya DNA babi dalam suplemen gizi pada cangkang kapsulnya oleh Badan Pengawas Obat dan Makanan (BPPOM) membuat masyarakat perlu teliti dan waspada dalam menggunakan obat-obatan khsususnya dalam bentuk sediaan kapsul (Firmansyah 2018). Selain itu sangat dimungkinkan sediaan obat dalam bentuk tablet juga menggunakan gelatin sebagai bahan pengikatnya. Lachman et al (1976) menyatakan bahwa semua bahan-bahan tambahan yang digunakan dalam pembuatan tablet, dan dari semua bahan-bahan yang tercantum, hanya gelatin yang merupakan bahan tambahan dari golongan protein. Jika menggunakan gelatin babi sudah tentu obat tersebut menjadi haram, namun jika menggunakan gelatin sapi, obat tersebut bisa menjadi halal maupun tidak halal. Hukumnya halal jika gelatin sapi yang digunakan itu telah memiliki Sertifikat Halal. Penelitian ini bertujuan untuk mengisolasi dan menganalisis adanya gelatin dalam obat bentuk sediaan tablet.

\section{METODE PENELITIAN \\ Bahan dan Alat}

Bahan-bahan yang digunakan yaitu sampel obat sediaan tablet yang berbahan aktif bukan protein, aquades, asam asetat $10 \%$, asam pikrat jenuh, pereaksi biuret, arang aktif, $\mathrm{H}_{2} \mathrm{SO}_{4}$ pekat, pereaksi Molisch, dan standar gelatin sapi (Merck).

Alat-alat yang digunakan yaitu mortar, gelas piala, tabung reaksi, oven, corong, spektrofotometer, magnetic stirer, penangas air, termometer, dan pipet mikro.

\section{Metode Penelitian \\ Isolasi gelatin dalam sediaan obat tablet} Sebanyak $15 \mathrm{~g}$ sampel obat dihaluskan menggunakan mortar. Setelah halus, pindahkan sampel ke dalam gelas piala dan ditambahkan $10 \mathrm{~mL}$ aquades. Panaskan sampel pada suhu $37^{\circ} \mathrm{C}$ sampai $60^{\circ} \mathrm{C}$ sambil di aduk menggunakan magnetic stirer. Tambahkan asam asetat 10\% sebanyak $3 \mathrm{~mL}$ dan $30 \mathrm{~mL}$ asam pikrat jenuh kemudian campuran ini diaduk menggunakan magnetic stirer selama 1 jam. Endapan yang terbentuk lalu disaring dengan menambahkan aquades sampai warna kuning hilang. Endapan yang dihasilkan lalu dipanaskan di dalam oven bersuhu $50^{\circ} \mathrm{C}$ sampai kering ( Ferris 1996).

\section{Pembuatan Kurva Standar dan Penentuan Panjang Gelombang Maksimum.}

Larutan standar gelatin dibuat dalam berbagai konsentrasi dari 0, 1, 2, 4, 5, 6,8 , dan $10 \mathrm{mg} / \mathrm{ml}$. Sebanyak $0.5 \mathrm{ml}$ setiap standar dimasukkan dalam tabung reaksi berbeda. Setiap tabung ditambah dengan 4.5 $\mathrm{ml}$ pereaksi biuret, kemudian segera diaduk dengan vorteks. Campuran kemudian didiamkan selama 10-15 menit lalu diukur absorbansinya pada panjang gelombang maksimum, yaitu 577 nm. Panjang gelombang maksimum diperoleh dengan mengukur campuran standar dan pereaksi pada panjang gelombang 450-650 nm dengan selang $0.2 \mathrm{~nm}$. Panjang gelombang yang memiliki absorbansi maksimum merupakan panjang gelombang maksimum.

\section{Preparasi Sampel}

Serbuk gelatin hasil isolasi ditimbang sebanyak 1 gram kemudian dilarutkan dalam $20 \mathrm{ml}$ akuades. Campuran ini kemudian dipanaskan pada suhu $60{ }^{\circ} \mathrm{C}$ dan diaduk menggunakan magnetic stirer sampai larut. Setelah larut, campuran ini disaring menggunakan kertas saring dan diambil filtratnya. Filtrat kemudian ditambah dengan arang aktif sebanyak 1 gram dan disaring lagi dengan kertas saring dan kapas sampai larutan menjadi jernih. Larutan yang dihasilkan siap untuk diukur absorbansinya.

\section{Pengukuran Sampel}

Sebanyak $0.5 \mathrm{ml}$ larutan sampel dimasukkan ke dalam tabung reaksi yang bersih dan kering. Sebanyak $4.5 \mathrm{ml}$ pereaksi biuret kemudian ditambahkan ke dalam sampel. Campuran ini segera diaduk dengan vorteks dan didiamkan selama 10-15 menit. Campuran ini kemudian diukur absorbansinya pada panjang gelombang maksimum standar yang diperoleh (577) $\mathrm{nm}$. 
Pengukuran sampel dilakukan dengan dua kali ulangan (duplo).

\section{HASIL DAN PEMBAHASAN}

\section{Hasil ekstraksi gelatin pada sediaan obat tablet}

Hasil ekstraksi gelatin pada sediaan obat tablet berupa padatan serbuk berwarna putih sampai kekuningan. Adanya warna kuning menunjukkan bahwa sisa asam pikrat masih terikat pada sampel hasil ekstraksi gelatin. Hal ini akan sangat mengganggu saat pengukuran konsentrasi gelatin sehingga perlu dihilangkan. Penggunaan arang aktif untuk mengikat warna kuning dari asam pikrat sangat efektif sehingga dihasilkan larutan yang jernih dan siap untuk dianalisis.

Ferris (1996) menyatakan bahwa penggunaan asam asetat dan asam pikrat dapat digunakan untuk mengisolasi protein pada sampel susu, krim, dan mentega. Asam pikrat dengan nama IUPAC 2, 4, 6 Trinitrophenol (TNP) merupakan asam kuat yang ada di alam. Asam pikrat bersifat larut dalam air dan memiliki nilai pKa 0.38 (Srivastava et al 2017). Protein jika bereaksi dengan asam, maka kelarutannya dalam air akan berkurang. Hal ini karena asam akan bersaing dengan protein untuk berikatan dengan air. JIka asam kuat yang digunakan untuk mengendapkan protein maka proses pengendapannya akan semakin cepat dan endapan protein yang dihasilkan akan lebih banyak. Hasil ekstraksi yang didapatkan tidak murni mengandung gelatin saja namun juga mengandung karbohidrat. Hal ini diperlihatkan dengan adanya cincin ungu pada uji Molisch. Uji Molisch adalah uji yang didasari oleh reaksi karbohidrat oleh asam sulfat dan membentuk cincin furfural atau hidroksi metal furfural yang berwarna ungu. Semua sampel hasil ekstraksi gelatin pada sediaan obat positif mengandung karbohidrat. Harrow et al (1960) menyatakan bahwa gula pereduksi (contohnya glukosa) mampu bereaksi dengan asam pikrat dalam suasana basa membentuk asam pikramat dan asam glukonat. Hal ini mengindikasikan bahwa penggunaan asam pikrat mampu mengisolasi karbohidrat juga selain gelatin dalam sediaan obat tablet. Dalam pembuatan suatu tablet, sebagian besar bahan tambahan yang digunakan berasal dari karbohidrat contohnya sellulosa, dekstrosa, gom, laktosa dan lain - lain. Sebut saja bahan pengemulsi, adsorben, pengencer, penyalut, penghancur, pelincir, dan pembawa sebagian besar menggunakan karbohidrat sebagai bahan dasarnya (Ansel 2008).

Protein adalah makromolekul yang terdiri dari rantai asam amino yang dihubungkan oleh ikatan peptida membentuk rantai peptida dengan berbagai jenis asam amino. Protein dapat dihidrolisis oleh asam , basa, atau enzim tertentu dan menghasilkan campuran asam - asam amino. Pada umumnya protein sangat peka terhadap pengaruh-pengaruh fisik dan zat kimia hingga mudah mengalami perubahan bentuk yang dinamakan denaturasi. Protein yang mengalami denaturasi akan menurunkan aktifitas biologi dan kelarutannya. Gelatin adalah produk alami yang merupakan hasil hidrolisis parsial kolagen. Lima asam amino yang ada umumnya meliputi glisin $26.4 \%$ $30.5 \%$, prolin $14.8 \%-18 \%$, hidroksiprolin $13.3 \%$ - $14.5 \%$, asam glutamat $11.1 \%$ $11.7 \%$, dan alanin $8.6 \%-11.3 \%$ (Grobben et al 2004). Berdasarkan hal ini, dapat dipastikan bahwa sifat fisik kimia gelatin dan protein adalah sama. Salah satunya adalah mampu terhidolisis dan terdenaturasi oleh asam. Salah satu keuntungan dari penggunaan asam pikrat dan asam asetat adalah mengurangi proses hidrolisis dan denaturasi. Selain itu perlakuan dan preparasinya sangat sederhana dan filtrat yang dihasilkan dari hasil isolasi dapat langsung digunakan sebagai sampel dan bisa langsung dianalisis( Ferris 1996).

\section{Pengukuran konsentrasi gelatin pada sampel \\ Metode Biuret didasarkan pada} pembentukan kompleks berwarna antara ikatan peptida dengan garam tembaga yang ada pada pereaksi. Garam tembaga yang terdapat pada pereaksi hanya akan membentuk kompleks dengan senyawa yang memiliki ikatan peptida. Pembentukan kompleks warna antara garam tembaga dengan asam amino tidak dapat terjadi. 
Adanya gelatin dalam sampel ditandai dengan perubahan larutan dari biru menjadi ungu. Semakin ungu warna larutan maka dapat dipastikan konsentrasi gelatin dalam sampel semakin besar.

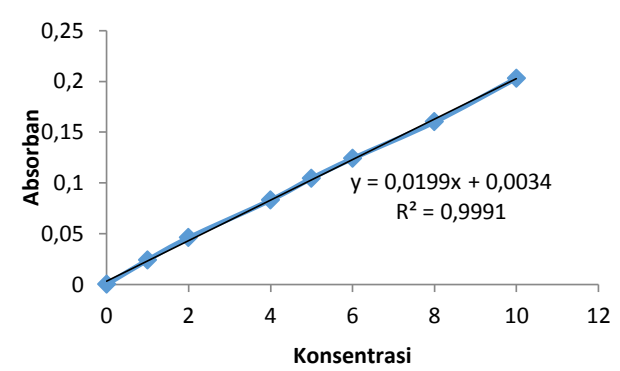

Gambar 1. Data Hasil Kurva Standar Gelatin

Untuk menghitung besarnya konsentrasi gelatin pada sampel, maka digunakan persamaan yang berasal dari hasil kurva standar gelatin. Hasil yang diperoleh dari pengukuran konsentrasi gelatin, hanya pada obat 5 dan 8 yang tidak mengandung gelatin. Konsentrasi gelatin terbesar terdapat pada obat 1 sebesar $66.84 \mathrm{mg} / \mathrm{mL}$ sedangkan konsentrasi terkecil diperoleh oleh obat 9 sebesar $1.05 \mathrm{mg} / \mathrm{mL}$. Adanya gelatin pada sampel obat mengindikasikan bahwa obat obat tersebut menggunakan gelatin sebagai bahan pengikat tabletnya. Sedangkan pada obat 5 dan 8 yang tidak mengandung gelatin, bahan pengikat tablet yang digunakan bisa dari golongan karbohidrat. Ansel (2008) menyatakan bahwa diantara bahan pengikat yang digunakan adalah $10-$ $20 \%$ cairan berair yang dibuat dari tepung jagung, 25-50\% larutan glukosa, molase, macam - macam gom alam, turunan selulosa, gelatin dan povidon. Selain itu bentuk sediaan bahan farmasetik dan produk formulasi, gelatin dapat ditemukan dalam bentuk zat pengenkapsulasi dan pengikat tablet (Ansel 2008).

Tabel 1 Hasil analisis Gelatin menggunakan pereaksi Biuret

\begin{tabular}{ccc}
\hline $\begin{array}{c}\text { Kode } \\
\text { Obat }\end{array}$ & $\begin{array}{c}\text { Konsentra } \\
\text { si gelatin } \\
(\mathrm{mg} / \mathrm{mL})\end{array}$ & Fungsi Obat \\
\hline Obat 1 & 66.84 & antibiotik \\
\hline Obat 2 & 5.26 & Obat hiperurisemia \\
\hline
\end{tabular}

\begin{tabular}{ccc}
\hline & & dan gout \\
\hline Obat 3 & 26.84 & Obat Flu \\
\hline Obat 4 & 2.63 & Obat batuk dan pilek \\
\hline Obat 5 & 0 & Obat batuk \\
\hline Obat 6 & 3.68 & $\begin{array}{c}\text { Analgesik dan } \\
\text { antipiretik }\end{array}$ \\
\hline Obat 7 & 5.79 & Antidiare \\
\hline Obat 8 & 0 & Trombolitik \\
\hline Obat 9 & 1.05 & $\begin{array}{c}\text { Obat hiperurisemia } \\
\text { dan gout }\end{array}$ \\
\hline $\begin{array}{c}\text { Obat } \\
10\end{array}$ & 1.58 & Obat batuk \\
\hline $\begin{array}{c}\text { Obat } \\
11\end{array}$ & 3.16 & Obat batuk \\
\hline
\end{tabular}

Dari 11 sampel yang dianalisis, terdapat 2 jenis obat yang kemungkinan sama jenisnya dan sudah dianalisis oleh Praira (2008) yaitu obat 3 dan obat 8 . Hasil Praira (2008) menunjukkan bahwa obat 3 dan 8 positif mengandung gelatin. Sedangkan pada penelitian ini, hanya obat 3 yang menunjukkan adanya gelatin sedangkan pada obat 8 tidak menunjukkan adanya gelatin. Hal ini dapat diartikan bahwa produsen obat 3 kemungkinan dari tahun 2008 sampai tahun 2018 masih menggunakan gelatin sebagai bahan pengikat tabletnya sedangkan produsen obat 8 sudah mengganti bahan pengikat tabletnya dengan bahan lain selain gelatin. Tidak terdeteksinya gelatin baik pada obat 5 dan obat 8 hasil ekstraksi menunjukkan bahwa produsen obat tidak menggunakan gelatin sebagai bahan pengikat tabletnya namun menggunakan bahan lain seperti gom, etilselulosa dan metal selulosa (Ansel 2004).

Seiring berkembangnya ilmu pengetahuan,telah banyak dikembangkan bahan pengganti gelatin sebagai bahan pengikat tablet. Hal ini dimaksudkan untuk memberikan rasa aman kepada konsumen khususnya masyarakat muslim mengingat gelatin belum tentu halal jika digunakan. Anwar (2004) menyatakan bahwa maltodekstrin DE 15-20 dapat digunakan sebagai bahan pengisi, pengikat dan penghancur dalam tablet yang diproses cara cetak langsung menggunakan furosemid sebagai model obat. Hano et al (2015) melaporkan bahwa penggunaan getah kulit buah Pisang Goroho pada konsentrasi 25\% memenuhi persyaratan sebagai bahan 
pengikat pada sediaan tablet klorfeniramin maleat. Sapri et al (2012) melaporkan bahwa pati biji cempedak juga dapat digunakan sebagai bahan pengikat dalam pembuatan tablet parasetamol secara granulasi basah. Adanya alternatif lain untuk mengganti gelatin diharapkan kedepannya para produsen obat mau mengganti bahan pengikat obatnya menjadi gelatin yang telah mempunyai sertifikat halal atau bahan lain yang jelas kehalalannya yang ditunjukkan dengan adanya logo atau label halal pada kemasan produknya atau gelatin yang digunakan oleh industri farmasi itu didukung oleh dokumen berupa sertifikat halal.

\section{KESIMPULAN}

Hasil menunjukkan bahwa dari 11 sampel sediaan obat tablet, diketahui 9 sampel teridentifikasi mengandung gelatin dengan konsentrasi yang berbeda - beda. Konsentrasi gelatin terbesar sebesar 66.84 $\mathrm{mg} / \mathrm{mL}$ pada obat 1 dan konsentrasi gelatin terkecil sebesar sebesar $1.05 \mathrm{mg} / \mathrm{mL}$ pada obat 9. Selain itu hasil isolasi gelatin menggunakan asam pikrat dan asam asetat pada sediaan obat tablet teridentifikasi mengandung karbohidrat pada semua sampel.

\section{DAFTAR PUSTAKA}

Anwar E . 2004. Pemanfaatan Maltodekstrin Pati Terigu sebagai Eksipien dalam Formula Sediaan Tablet dan Niosom. Majalah Ilmu Kefarmasian. I(1): 34-46.

Ansel HC. 2008. Pengantar bentuk sediaan farmasi. Jakarta : UI Press.

Ferris LW. 1996. A Method For The Determination Of Amino Nitrogen And Ammonia In Cream And Butter. Food Control Laboratory, Bureau of Chemistry, United States Department of Agriculture

Firmansyah T. 2018. Ini mengapa perusahaan obat Banyak Pakai Gelatin dari babi.

https://m.republika.co.id/berita/duniaislam/islamnusantara/18/02/01/p3gacq377-ini mengapa-perusahaan-obat-banyakpakai-gelatin-dari-babi. [12 September 2018].

Grobben AH, Steele PJ, Somerville RA, Taylor DM. 2004. Inactivation of the ovine - spongiform- encephalopathy (BSE) agent by the acid and alkali processes used the manufacture of bone gelatin. Biothecnology and Applied Biochemistry. 39 : $329-338$.

Hano, Lemborano N., Paulina Y, dan Hamidah S. 2015. Formulasi Tablet Klorfeniramin Maleat dengan Bahan Pengikat Getah Kulit Buah Pisang Goroho (Musa Acuminafe L) menggunakan Metode Granulasi Basah. PHARMACON, JurnalImiah Farmasi UNSRAT. 4(3): 29- 33.

Harrow B, Borek, Mazur A, Stone GCH, Wagreich H. 1960. Laboratory Manual of Biochemistry. London : W.B Saunders Company

Hermanto S, Nurlely A, Heryanto R. 2015. Diferensiasi Gelatin Asal Hewan Pada Produk Permen Jelly Komersil Menggunakan FTIR dan Kalibrasi Multivariat. Prosiding. World Academic $\&$ research Congress 2015 .

Lachman L, Lieberman HA, Kanig JL. 1976. Teori dan Praktek Farmasi Industri. Suyatmi S, penerjemah; Jakarta: UI Pr.

Rowe, R. C., P. J. Sheskey dan M. E. Quinn. 2009. Handbook of Pharmaceutical Excipients Sixth Edition. Pharmaceutical Press and American PharmacistsAssociation. USA

Sahilah AM., Norrakiah M, Aminah AS, Wan A, A. W. M.,Ma'ruf, Mohd KA. 2012. Halal Market Surveillance of Soft and Hard Gel Capsules in Pharmaceutical Products using PCR and Southern- Hybridization on the Biochip Analysis. International Food and ResearchJournal, 19(1): 371-375.

Sapri, Dedi Setiawan, dan Rizki K. 2012. Pengaruh Penggunaan Pati Biji Cempedak (Arthocarpus Champeden Lour) sebagai Bahan Pengikat terhadap Sifat Fisik Tablet Parasetamol secara Granulasi Basah. J. Trop. Pharm. Chem.2(1): 47-61.

Srivastava KK, Shubha S, Md Tanweer, Rituraj. 2017. An Overview of Picric acid. Der Pharma Chemica. 9(9) : 64 75.

Zhang, G., T. Liu, Q. Wang, L. Chen, J. Luo, G. Ma, Z. Su. 2009. Mass Spectrometric Detection of Marker Peptides in Tryptic Digests of Gelatin: A New Method to Differentiate 
Jurnal EnviScience Vol. 2 No. 2 September 2018

Between Bovine and Porcine Gelatin.

FoodHydrocolloids. 23: 2001-2007 